\title{
VÝUKA MUZEOLOGIE NA VEŘEJNÝCH VYSOKÝCH ŠKOLÁCH V ČR (ROZSAH A CHARAKTER VÝUKY)
}

\section{FRANTIŠEK ŠEBEK}

V muzeích, galeriích

a samostatných zpřístupněných památnících ČR (dále jen muzea) pracuje $\mathrm{v}$ současné době bezmála 9 tisíc zaměstnanců. ${ }^{1} \mathrm{~V}$ přepočtu na plně zaměstnané osoby to je zhruba 6 tisíc osob (celých pracovních úvazků) a $\mathrm{z}$ toho je $\mathrm{k}$ uvedenému datu vykázáno bezmála 3000 odborných pracovníků (plně zaměstnaných osob), ${ }^{2}$ u nichž se vesměs předpokládá vysokoškolské vzdělání. Skutečný počet vysokoškolsky kvalifikovaných zaměstnanců ale $\mathrm{v}$ muzeích neznáme. Osobně odhaduji, že to je asi $80 \%$ zmíněné kategorie odborných pracovníků v přepočtu

1 Tento údaj a níže uvedená statistická data o počtu zaměstnanců v muzeích ČR s podrobnějším komentářem viz ŠEBEK František a kol. Muzea ČR v letech 2012-2014. Praha: NIPOS, 2015, s. 21-22. ISBN 978-80-7068-300-2.

2 Konkrétně to bylo k roku 2014 v přepočtu na plně zaměstnané osoby 2971 odborných pracovníků. $\mathrm{Z}$ tohoto počtu bylo $\mathrm{k}$ roku

2014 ve státních muzeích (27 institucí) 1150 odborných pracovníků (tj. asi $42 \%$ z celkového počtu odborných pracovníků), v muzeích zřizovaných kraji jich bylo 1249 (94 institucí) v muzeích zřizovaných městy a obcemi to je 323 odborných pracovníků (253 institucí) a zbytek, tj. 249 pracovních úvazků, připadá na muzea ostatních zřizovatelů. (Údaje jsou převzaty z práce citované v pozn. 1). Pro účely muzejní statistiky (výkaz Kult (MK) 14-01) se jako odborní pracovníci vykazují vědečtí pracovníci (výzkumní a vývojoví pracovníci), kurátoři sbírek, odborní knihovníci, kvalifikovaní konzervátoři, restaurátoři, preparátoři, muzejní pedagogové, lektoři a pracovníci managementu (tj. ředitelé nebo vedoucí muzeí a jejich náměstci, vedoucí ekonomové, vedoucí organizačních útvarů zajištujících odbornou správu muzejních sbírek nebo prezentační činnosti muzea), přičemž pojmenování jejich pozice v organizační struktuře instituce a dosažené nejvyšší vzdělání není pro výkaz rozhodující. Počet odborných pracovníků se vykazuje $\mathrm{v}$ přepočtu na plně zaměstnané osoby. Je-li zaměstnanec odborným pracovníkem podle této klasifikace jenom z části svého úvazku (tj. plní pravidelně a ve větším rozsahu též úkoly, které nespadají do kategorie odborný pracovník), uvede se reálným odhadem poměrná část úvazku tohoto zaměstnance připadající na činnosti odborného pracovníka. na plně zaměstnané osoby, počítáme-li fyzické osoby, odhadem 2,5 tisíce zaměstnanců. Neexistuje bohužel nějaký celistvý přehled o profesní struktuře ani o reálné oborové skladbě těchto pracovníků, nevíme nic bližšího o dynamice jejich personální obměny, respektive fluktuaci. Zmíněná kategorie odborných pracovníků $s$ převážně vysokoškolskou kvalifikací je přitom pro kvalitu výkonů našich muzeí klíčová, protože oni jsou rozhodujícím elementem pro tvorbu muzejních sbírek, jejich uchování a ochranu, zpřístupnění veřejnosti, oni také koneckonců ovlivňují koncepční směřování svých institucí i oboru jako celku.

V návaznosti na toto konstatování je jistě namístě také otázka, s jakými znalostmi o muzejní profesi přicházejí do těchto institucí absolventi vysokoškolského studia různých specializovaných oborů. Pokusil jsem se proto zmapovat aspoň rozsah a zaměření výuky muzeologie, respektive různě modifikovaných úvodů do teorie a praxe muzejnictví (dále budu užívat jen obecný termín muzeologie) na našich veřejných vysokých školách. Stranou mého šetření zůstaly vysoké školy a studijní obory, které umožňují získat kvalifikaci takovým specializovaným pracovníkům, jako jsou konzervátoři, restaurátoři a příbuzné profese, dále též případným muzejním grafikům a výtvarníkům; neposuzoval jsem ani specializované studijní obory arts managementu na několika domácích vysokoškolských pracovištích. Nebral jsem samozřejmě zřetel ani na kvalifikaci pro pracovní pozice ekonomů, pracovníků IT útvarů atd. Stranou mého rozboru zůstalo ale také jednooborové nebo dvouoborové studium muzeologie v bakalářském, případně i navazujícím magisterském studiu, které nabízí Filozofická fakulta Masarykovy univerzity v Brně nebo Filozoficko-přírodovědecká fakulta Slezské univerzity v Opavě. Tento typ muzeologického vzdělání, pojatého na obou zmíněných fakultách poněkud odlišně, by si vyžádal samostatnou analýzu a hlubší zamyšlení. Můj zájem se tedy soustředil na školy, kde se studuje $\mathrm{v}$ různých variantách předmět muzeologie koncipovaný jako součást tzv. profesní přípravy při studiu různých oborů a studijních programů, u nichž se deklaruje eventuelní pracovní uplatnění absolventů i v muzejních institucích. Výsledkem mého šetření je zjištění, že vyučovací předměty muzeologie naznačeného zaměření se objevují ve studijních programech devíti univerzit. Jsou to Univerzita Karlova v Praze, Jihočeská univerzita v Českých Budějovicích, Západočeská univerzita v Plzni, Univerzita J. E. Purkyně v Ústí n. L., Technická univerzita v Liberci, Univerzita v Hradci Králové, Univerzita Pardubice, Ostravská univerzita a Univerzita Palackého v Olomouci. Odtud (a samozřejmě také $\mathrm{z}$ Brna a Opavy) přicházejí pracovat do muzeí kurátoři muzejních sbírek, výzkumní pracovníci a tvůrci muzejních výstavních 
a jiných výchovně vzdělávacích programů pro veřejnost, kteří jsou absolventy studia specializovaných přírodovědeckých oborů, archeologie, historie, etnologie, historie umění, pedagogických věd atd. Vědomosti absolventů těchto škol o specifičnosti práce, kterou mají v muzeích vykonávat, jsou vskutku rozmanité a předně na nestejné úrovni. Stručný přehled o rozsahu a charakteru výuky muzeologie na zmíněných devíti univerzitách je uveden v př́loze v tabulkách 1-9. Data pro jejich sestavení jsem získal $\mathrm{z}$ veřejně dostupných internetových prezentací plánů výuky ve studijních programech a studijních oborech všech zmíněných škol (vesměs bylo využito dat z portálů STAG) v akademickém roce $2015 / 2016$; přihlížel jsem k eventuelním zásadním změnám studijních plánů v akad. r. 2016/2017.

Na základě shromážděných údajů lze dospět $\mathrm{k}$ několika závěrům:

\section{Až na výjimky se předmět muzeologie nevyučuje na přírodovědeckých fakultách,} odkud nastupují do muzeí kurátoři přírodovědných sbírek. Ti tedy vesměs přicházejí do muzeí znalostmi o specifičnosti této profese zcela nedotčeni. Ony výjimky představují studenti přírodovědeckých oborů na univerzitách v Brně a Opavě, pokud si zapíší jako druhý studijní obor muzeologii. Do určité míry můžeme $\mathrm{k}$ těmto výjimkám snad ještě zařadit studenty Př́rodovědecké fakulty UK v Praze, studijního oboru Antropologie, kteří mají ve studijním plánu zařazen $v$ jednom semestru bakalářského studia seminář 1 hod. týdně konaný v antropologickém oddělení Národního muzea.

2. O mnoho lépe na tom nejsou ani studijní obory ze studijního programu archeologie. $\mathrm{Na}$
FF UK Praha se muzeologie přednáší v bakalářském studiu oboru Klasická archeologie jeden semestr 2 hod. týdně a vedle toho je 7-denní praxe v muzeu. Na univerzitě v Plzni je v bakalářském studiu oboru Archeologie zařazena $\mathrm{v}$ jednom semestru přednáška 2 hod. týdně (muzeologie a památky), v Hradci Králové je v bakalářském studiu $\mathrm{v}$ jednom semestru přednáška 1 hod. týdně (archeologie v muzeu). A potom už zbývá jenom obdobná možnost dvouoborového studia na univerzitách v Brně a Opavě.

\section{Velice pestrá je škála předmětů} muzeologie $\mathrm{v}$ různých studijních oborech z programu historické vědy. Nesrovnatelně lépe jsou ale zastoupeny předměty muzeologie u studijních oborů typu dějin umění a na pedagogických fakultách u oborů výtvarná výchova a vzdělávání (různé varianty oborů). Ve většině těchto studijních oborů jsou muzeologické výklady rozloženy do dvou a více semestrů a mají tedy větší dotaci vyučovacích hodin, jsou také více zaměřeny na konkrétní pracovní činnosti v muzeích umění (galeriích), zejména pokud jde o metody prezentace výtvarného díla. Na dvou univerzitách je dokonce nabízen muzeologicky zaměřený studijní program orientující se hlavně na práci galerií. Na Fakultě umění a designu Univerzity J. E. Purkyně v Ústí n. L. je to dvouleté navazující magisterské studium v programu Kurátorská studia a na Pedagogické fakultě Univerzity Palackého v Olomouci program v navazujícím magisterském studiu Muzejní a galerijní pedagogika, koncipovaný jako dvouoborové studium. Ze studijních plánů je i zde patrný akcent na práci galerií. Jednoduše řečeno, profesní příprava studentů oborů výtvarného umění (včetně výtvarné výchovy a vzdělávání) pro práci v galeriích je až na několik málo výjimek na nesrovnatelné lepší úrovni než v různých studijních oborech historických věd a výše zmíněné archeologie a u přírodovědeckých oborů.

4. U studijních oborů v rámci studijních programů historické vědy si všimněme, že jenom menší část univerzit zařazuje do studijních plánů jednotlivých oborů předmět muzeologii (jeho různé varianty) do dvou a více semestrů. Často se na rozdíl od výše zmíněných programů výtvarného umění jedná toliko o výuku jednoho předmětu muzeologie $\mathrm{v}$ rozsahu jednoho semestru. Pro ilustraci šíře rozdílů uved’me, že například posluchači oboru historie na FF UK mají muzejní profesní přípravu až v navazujícím magisterském studiu u oboru České dějiny, kde je jenom $v$ jednom semestru pouze seminář s dotací 2 hod. týdně. Naproti tomu na FF Univerzity Pardubice je u bakalářského studia v oboru Kulturní dějiny zařazena muzeologie po dva semestry s dotací 2 hod. přednášek týdně každý semestr a vedle toho semináře $s$ dotací rovněž 2 hod. týdně. Na to navazuje semestrový výklad o katalogizačních a evidenčních programech v muzejnictví (1 hod. přednášky a 1 hod. seminář týdně). Studenti mají ještě na to navazující praxi. Slušná je také dotace muzeologických předmětů též na Fakultě přírodovědněhumanitní a pedagogické Technické univerzity v Liberci u oboru Kulturně historická a muzeologická studia. Studenti tu mají povinné muzeologické předměty během tří semestrů (historie muzejnictví a muzeologie I a II) a vedle toho dva předměty volitelné (kulturní management a výstavnictví galerie).

Zakončení předmětů muzeologie se v převažující míře děje formou přiznání zápočtu nebo dokonce jen formou kolokvia. $\mathrm{V}$ nemnoha 
případech se jedná o klasifikovaný zápočet a jen ojediněle je předmět muzeologie zakončen zkouškou ( 6 z $58 \mathrm{v}$ přehledu zaznamenaných předmětů).

\section{Za důležitou složku profesní} př́ipravy k muzejnictví považuji zapojení studentů do reálné praxe muzejních institucí.

Nemám tu ovšem na mysli jenom exkurze studentů v muzeích nebo krátkodobé pobyty, ale souvislé zapojení studentů do pracovních činností ve vybrané muzejní instituci aspoň po dobu 2 týdnů. To se ale kromě případů studijního oboru muzeologie na zmíněných fakultách $v$ Brně a Opavě, respektive při studiu Kurátorství sbírek v Ústí n. L. a Muzejní pedagogika v Olomouci, děje bohužel jenom sporadicky. Se zařazením muzejní praxe do studijních plánů se setkáme jenom $\mathrm{v}$ rámci bakalářského studia etnologie na FF UK Praha (10 dní) a tamtéž při již zmíněném studiu klasické archeologie (7 dní), na FF Ostravské univerzity při magisterském studiu oboru Historie a oboru Hospodářské a sociální dějiny novověku (v obou případech 8 dní) a na FF Univerzity Pardubice při bakalářském studiu oboru Kulturní dějiny (10 dní), oboru Ochrana hmotného kulturního dědictví $(2 \times 10$ dní) a v magisterském studiu $\mathrm{v}$ programech historických věd jako výběrový předmět (10 dní). To je všechno! Byt je zřejmé, že organizace takového typu výuky studentů předpokládá ochotu managementu vhodných muzejních institucí, vyřešení vzájemných smluvních vztahů a je organizačně poněkud náročná, nelze z konstatování o důležitosti této výuky nic slevit.

\section{Je otázka, jakou profesní} přípravu absolventů různých specializovaných oborů vysokoškolského studia by měly (mohly) muzejní instituce očekávat?
Pokusím se na to podívat pohledem člověka, který působil přes třicet let v muzejní manažerské funkci (1978-2009) ve středně velkém muzeu do 50 zaměstnanců, přicházel a přichází do kontaktu s mnoha pracovníky velkých i úplně malých muzeí, a posledních zhruba deset let vyučuje muzeologii na vysoké škole. Mám letitou zkušenost, že absolvent, který nastoupí do muzea, neumí bez ohledu na délku a hloubku studia muzeologie skoro vůbec nic. $\mathrm{Na}$ rozdíl od člověka, který nastoupí bez jakékoliv profesní přípravy, se ale průměrně schopný absolvent v muzejním prostředí a v „nové“ pro něj roli nepoměrně rychleji zorientuje a dokáže většinou brzy zmobilizovat útržky dříve slyšených (čtených) teoretických výkladů. Jde ale o to, aby měl co ve své paměti mobilizovat. Jsem přesvědčen, že ony kurzy dotované 13 nebo 26 vyučovacími hodinami výkladů během celého studia, často nepodepřené ani promyšlenou praxí, nejsou schopny cíl profesní přípravy absolventa vysokoškolského studia na zaměstnání v muzeu naplnit. Takový absolvent nemá podle mého přesvědčení ani šanci skoro co praktického mobilizovat a taková výuka plní cíl jenom formálně. Jsem přesvědčen, že absolventi předmětů muzeologie koncipovaných jako doplňující profesní příprava by měli aspoň tušit, co obnáší tvorba a odborná správa muzejních sbírek, včetně preventivní konzervace, co obnáší tvorba muzejních výstavních programů a co dělat, aby mělo muzeum co nejvíce spokojených návštěvníků a přízeň veřejnosti.

Tím se však už dostáváme za hranice zde proklamovaného komentáře $\mathrm{k}$ přehledu o rozsahu a charakteru vysokoškolské výuky muzeologie. Vyvstávají totiž před námi další otázky typu, kde jsou meze oné elementární profesní přípravy; jakou úlohu by mělo mít navazující muzeologické vzdělávání pracovníků se zkušenostmi z praxe (nepřesně řečeno: celoživotní vzdělávání); zda a eventuelně jakou souvislost na zmíněnou elementární profesní přípravu má nebo by mělo mít studium oboru muzeologie (viz fakulty Brno a Opava, případně Ústí n. L., Olomouc). Jsou to jistě složité otázky, na něž nebudeme mít odpověd' jen tak hned. Prozatím by asi stačilo, kdyby učitelé různých předmětů muzeologie, přednášených při různě koncipovaných studijních oborech $\mathrm{v}$ rámci studijních programů historické vědy, archeologie a etnologie, začali spolu vést dialog směřující $\mathrm{k}$ vymezení optimálního obsahového minima předmětů muzeologie koncipovaných jako elementární profesní př́íprava absolventů pro jejich př́ípadné profesní uplatnění v muzeích.

\section{PŘÍLOHA:}

\section{Přehled rozsahu a charakteru výuky muzeologie (muzejnictví) na sedmi univerzitách $\mathrm{v}$ ČR podle stavu v akad. roce 2015/2016}

\section{Vysvětlivky: \\ Sloupec označený jako:}

Studijní obor:

Za názvem studijního oboru je v závorce uvedeno, zda se jedná o bakalářský studijní program (Bc) nebo navazující magisterský studijní program $(\mathrm{Mg})$.

\section{Předmět:}

Uveden název předmětu v daném studijním oboru, jehož obsahem je poučení o muzejní teorii a praxi nebo se jedná o výuku formou praxe $\mathrm{v}$ muzejní instituci.

\section{Rozsah:}

Uvedena dotace hodiny výuky týdně během semestru. První číslo uvádí počet hodin týdně přednášek, druhé číslo počet hodin týdně 
seminářů. Je-li uveden počet dní, jedná se o rozsah praxe během celého semestru, která proběhne v muzejní instituci.

\section{Stat $=$ statut předmětu:}

A - předmět je pro studenty daného oboru povinný,

$B$ - předmět je pro studenty daného oboru povinně volitelný,
$\mathrm{C}$ - předmět je pro studenty daného oboru nepovinný, výběrově volitelný.

$E x=$ examinace, způsob zakončení:

Zk - předmět je zakončen zkouškou

$\mathrm{KZ}$ - předmět je zakončen

klasifikovaným zápočtem

$\mathrm{Zp}$ - předmět je zakončen

přiznáním zápočtu

Ko - předmět je zakončen formou

kolokvia, rozpravy
Vyučujicí:

Jména vyučujících a garantů předmětu jsou uvedena zkráceně bez titulů a akad. funkcí.

\begin{tabular}{|c|c|c|c|c|c|c|}
\hline Fak. & Studijní obor & Předmět & Rozsah & Stat & Ex & Vyučující \\
\hline $\begin{array}{l}\text { Př́írodovědecká } \\
\text { fakulta }\end{array}$ & Antropologie (Bc) & $\begin{array}{l}\text { Muzejnictví a kurátorství antro- } \\
\text { pol. sbírek }\end{array}$ & $0+1$ & B & $\mathrm{Zp}$ & Velemínský + prac. NM \\
\hline \multirow{3}{*}{$\begin{array}{l}\text { Pedagogická } \\
\text { fakulta }\end{array}$} & \multirow{2}{*}{$\begin{array}{l}\text { Výtv. výchova a vzdělávání } \\
\text { (Bc) }\end{array}$} & $\begin{array}{l}\text { Galerijní animace a muzejní } \\
\text { pedagogika }\end{array}$ & $1+2$ & $\begin{array}{l}\text { A, } \\
\text { B }\end{array}$ & $\mathrm{Zk}$ & Fulková \\
\hline & & $\begin{array}{l}\text { Galerijní animace - jen pro } \\
\text { modul VV }\end{array}$ & $0+2$ & $\begin{array}{l}\text { A, } \\
\text { B }\end{array}$ & $\mathrm{Zp}$ & Jakubcová - Hajdušková \\
\hline & $\begin{array}{l}\text { Různé obory učitelství na ZŠ } \\
\text { a SŠ (Bc) }\end{array}$ & Spolupráce školy a muzea & $0+1$ & B & $\mathrm{Zp}$ & Horská \\
\hline \multirow{4}{*}{$\begin{array}{l}\text { Fakulta humanit- } \\
\text { ních studií }\end{array}$} & $\begin{array}{l}\text { Orální historie - soudobé } \\
\text { dějiny }(\mathrm{Bc})\end{array}$ & $\begin{array}{l}\text { Archivy, badatelské instituce } \\
\text { a muzea v bádání o soudobých } \\
\text { děj. }\end{array}$ & $0+2$ & B & $\mathrm{Zp}$ & Krátká \\
\hline & $\begin{array}{l}\text { Studium humanitní vzděla- } \\
\text { nosti - Historický modul (Bc) }\end{array}$ & Muzeologie & $2+0$ & A & $\mathrm{KZ}$ & Zaoral \\
\hline & \multirow{2}{*}{$\begin{array}{l}\text { Studium humanitní vzděla- } \\
\text { nosti - Kreativní modul (Bc) }\end{array}$} & Základy muzejních studií & $0+2$ & A & $\mathrm{KZ}$ & Kreuzzieger \\
\hline & & Základy výstavní praxe & $0+2$ & B & $\mathrm{KZ}$ & Zavadil \\
\hline \multirow{8}{*}{ Filozofická fakulta } & \multirow{2}{*}{ Klasická archeologie (Bc) } & Muzeologie & $2+0$ & A & $\mathrm{Zk}$ & Kocichová \\
\hline & & Muzejní praxe & 7 dní & B & $\mathrm{Zp}$ & Vacinová \\
\hline & \multirow{2}{*}{ Etnologie, folkloristika (Bc) } & Muzeologie & $2+0$ & B & Zk & Štěpánová \\
\hline & & Muzejní reálie & 10 dní & B & Zp & Štěpánová \\
\hline & $\begin{array}{l}\text { Hospodářské a sociální } \\
\text { dějiny }(\mathrm{Mg})\end{array}$ & $\begin{array}{l}\text { Historici v muzeu: Teoretický } \\
\text { a praktický kurz muzejních } \\
\text { studií }\end{array}$ & $2+0$ & B & Ko & Jareš \\
\hline & \multirow{2}{*}{$\begin{array}{l}\text { Inform. techn. a knihovnictví } \\
\text { (Bc) }\end{array}$} & Muzejnictví I & $0+4$ & B & $\mathrm{Zp}$ & Stehlík a prac. NM \\
\hline & & Muzejnictví II & $0+4$ & B & $\mathrm{Zp}$ & Stehlík a prac. NM \\
\hline & České dějiny (Mg) & Muzejnictví & $0+2$ & B & $\mathrm{Zp}$ & Stehlík \\
\hline
\end{tabular}

Tab. 1: Univerzita Karlova v Praze

\begin{tabular}{|c|c|c|c|c|c|c|}
\hline Fak. & Studijní obor & Předmět & Rozsah & Stat & Ex & Vyučující \\
\hline \multirow{3}{*}{ Filozofická fakulta } & \multirow{2}{*}{$\begin{array}{l}\text { Archivnictví (Mg); } \\
\text { Historie (Mg) }\end{array}$} & Muzeologie a památková péče I & $2+1$ & A, B & $\mathrm{Zk}$ & Gaži \\
\hline & & Muzeologie a památková péče II & $2+1$ & A, B & $\mathrm{Zp}$ & Skořepová \\
\hline & Dějiny umění (Bc) & Muzeum a galerie $\mathrm{v}$ praxi & $2+2$ & A & $\mathrm{Zk}$ & Horníčková \\
\hline
\end{tabular}

Tab. 2: Jihočeská univerzita v Českých Budějovicích 


\begin{tabular}{|l|l|l|l|l|l|l|}
\hline Fak. & Studijní obor & Předmět & Rozsah & Stat & Ex & Vyučující \\
\hline \multirow{2}{*}{ Filozofická fakulta } & $\begin{array}{l}\text { Archeologie (Bc), též pro obor Huma- } \\
\text { nistika (Bc),w pro obor Evropská kult. } \\
\text { studia (Mg) }\end{array}$ & Muzeologie a památky & $2+1$ & B & Zp & Frýda \\
\hline \multirow{2}{*}{ Fakulta designu } & Umění a užité umění (Mg) & Galerijní praxe & nespecif. & A & Zp & Lukavský ad. \\
\cline { 2 - 7 } & Umění a užité umění; jiné obory (Bc) & $\begin{array}{l}\text { Galerijní praxe a způsoby sebe- } \\
\text { realizace }\end{array}$ & $0+2$ & B & Zp & Tomková ad. \\
\hline \multirow{2}{*}{$\begin{array}{l}\text { Pedagogická } \\
\text { fakulta }\end{array}$} & $\begin{array}{l}\text { Učitelství výtvarné výchovy pro ZŠ; } \\
\text { pro SŠ́ pro pedagogické školy (Mg) }\end{array}$ & Galerijní pedagogika & $2+1$ & A, B & Zp & Slavík ad. \\
\cline { 2 - 7 } & $\begin{array}{l}\text { Vizuální kultura se zaměřením na } \\
\text { vzdélávání (Bc) }\end{array}$ & Galerijní animace & $2+1$ & A & Zp & Slavík \\
\hline
\end{tabular}

Tab. 3: Západočeská univerzita v Plzni

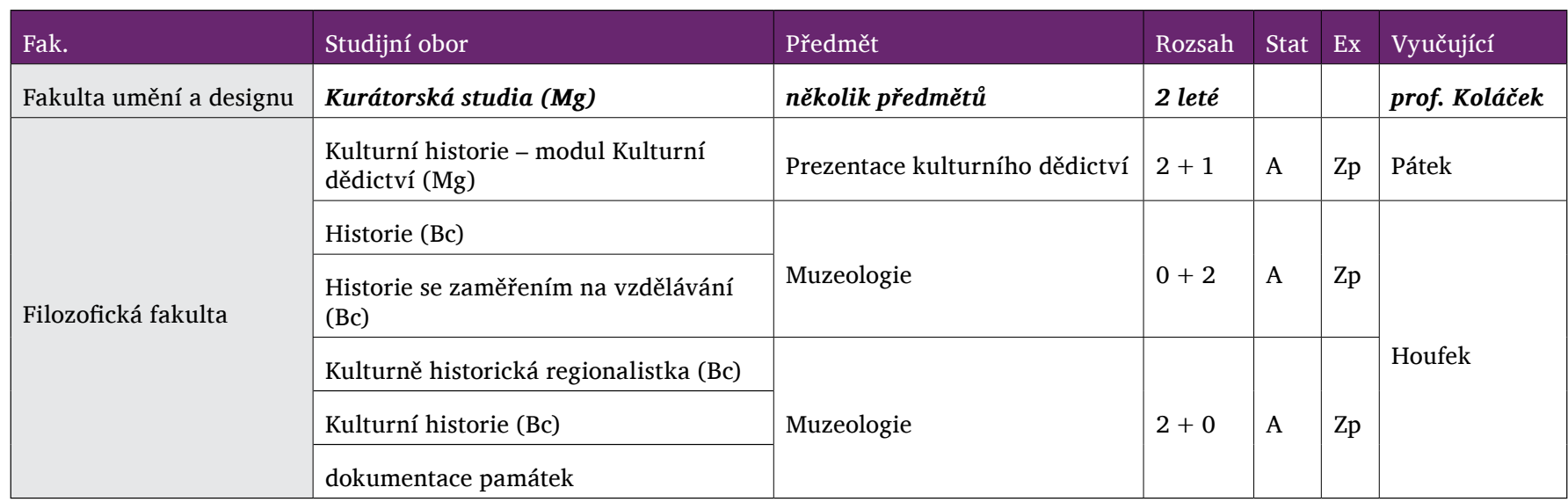

Tab. 4: Univerzita J. E. Purkyně v Ústí nad Labem

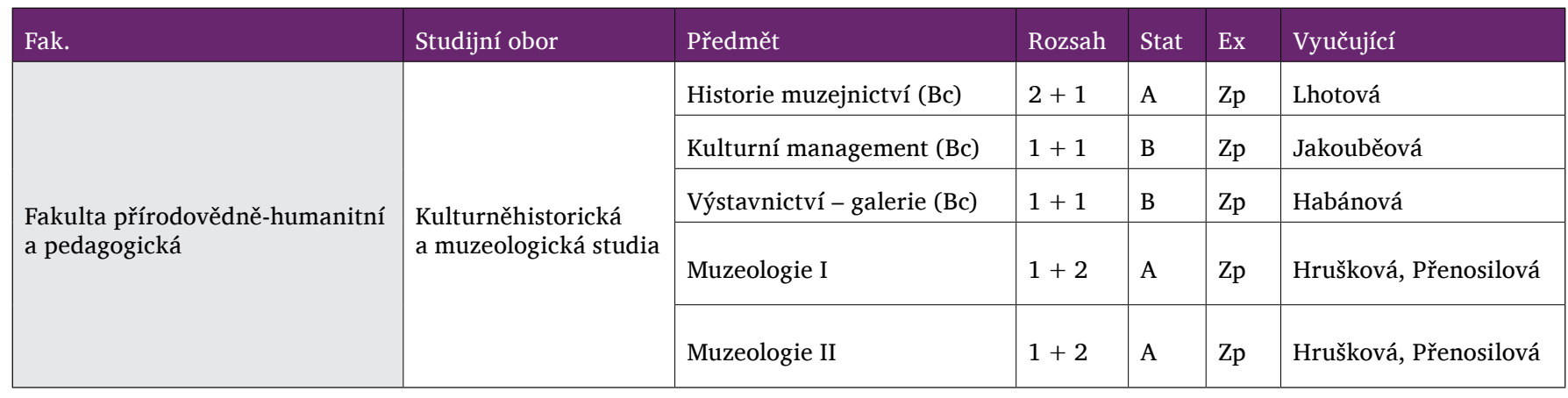

Tab. 5: Technická univerzita v Liberci

\begin{tabular}{|c|c|c|c|c|c|c|}
\hline Fak. & Studijní obor & Předmět & Rozsah & Stat & Ex & Vyučující \\
\hline \multirow{5}{*}{ Fakulta filozofická } & Archeologie (Bc) & Archeologie v muzeu & $1+0$ & A & $\mathrm{Zp}$ & Tichý \\
\hline & \multirow{4}{*}{$\begin{array}{l}\text { Prezentace a ochrana kultur- } \\
\text { ního dědictví (Bc), } \\
\text { (též archivnictví - Bc) }\end{array}$} & Veřejnoprávní aspekty kultury & $2+0$ & A & $\mathrm{Zp}$ & Zahradník \\
\hline & & Základy muzeologie & $2+0$ & A & $\mathrm{ZK}$ & Havlík \\
\hline & & Základy knihovnictví a muzejnictví & $1+1$ & A, B & $\mathrm{Zp}$ & Zahradník \\
\hline & & Právo a management kult. instituce & $1+0$ & A & $\mathrm{Zp}$ & Machková Prajzová \\
\hline \multirow{2}{*}{$\begin{array}{l}\text { Pedagogická } \\
\text { fakulta }\end{array}$} & \multirow{2}{*}{$\begin{array}{l}\text { Výtvarná tvorba se zamě- } \\
\text { řením na vzdělávání }\end{array}$} & Galerijní animace 1 & $1+1$ & B & Zp & Zářecká \\
\hline & & Galerijní animace 2 & $1+0$ & B & $\mathrm{Zp}$ & Zářecká \\
\hline
\end{tabular}

Tab. 6: Univerzita v Hradci Králové 


\begin{tabular}{|c|c|c|c|c|c|c|}
\hline Fak. & Studijní obor & Předmět & Rozsah & Stat & Ex & Vyučující \\
\hline \multirow{9}{*}{$\begin{array}{l}\text { Fakulta } \\
\text { Filozofická }\end{array}$} & \multirow{6}{*}{ Kulturní dějiny (Bc) } & Muzeologie I & $2+0$ & A, B & $\mathrm{Zp}$ & \multirow{9}{*}{ Šebek } \\
\hline & & Muzeologie I a seminář & $0+2$ & A & $\mathrm{Zp}$ & \\
\hline & & Muzeologie II & $2+0$ & A, B & ZK & \\
\hline & & Muzeologie II a semináŕ & $0+2$ & A & $\mathrm{Zp}$ & \\
\hline & & $\begin{array}{l}\text { Katalogizační a evidenční programy } \\
\text { pro muzejnictví }\end{array}$ & $1+1$ & B & $\mathrm{Zp}$ & \\
\hline & & Katalogizace sbírek VČM Pardubice & 10 dní & B & $\mathrm{Zp}$ & \\
\hline & \multirow{3}{*}{$\begin{array}{l}\text { Ochrana hmotného kulturního } \\
\text { dědictví (Bc) }\end{array}$} & Úvod do muzejnictví & $2+1$ & A & $\mathrm{Zp}$ & \\
\hline & & Muzejní odborná praxe I & 10 dní & B & Zp & \\
\hline & & Muzejní odborná praxe II & 10 dní & B & $\mathrm{Zp}$ & \\
\hline
\end{tabular}

Tab. 7: Univerzita Pardubice

\begin{tabular}{|c|c|c|c|c|c|c|}
\hline Fak. & Studijní obor & Předmět & Rozsah & Stat & Ex & Vyučující \\
\hline \multirow{4}{*}{ Filozofická fakulta } & $\begin{array}{l}\text { Historie (Bc), České a čsl. dějiny (Bc), } \\
\text { Medievistika (Mg) }\end{array}$ & Základy muzeologie & $2+1$ & $\begin{array}{l}\text { A } \\
\text { B }\end{array}$ & $\mathrm{ZK}$ & Vojtal \\
\hline & $\begin{array}{l}\text { Historie (Mg), Hospodářské a sociální } \\
\text { dějiny novověku (Mg) }\end{array}$ & Praktikum v muzeích & 8 dní & $\begin{array}{l}\text { A } \\
\text { B }\end{array}$ & $\mathrm{Zp}$ & Zářický \\
\hline & $\begin{array}{l}\text { Historie a ochrana průmyslového dědic- } \\
\text { tví }(\mathrm{Mg}) \text {, Dějiny umění se zaměřením na } \\
\text { památkovou péči }(\mathrm{Bc}) \text {, Kulturní dějiny } \\
(\mathrm{Mg}) \text {, Incoming Students (Bc a } \mathrm{Mg} \text { ) }\end{array}$ & $\begin{array}{l}\text { Kulturologie, muzeologie } \\
\text { a monumentika }\end{array}$ & $2+1$ & $\begin{array}{l}\mathrm{B}, \\
\mathrm{C}\end{array}$ & $\mathrm{Zp}$ & Zatloukal, Jordánová \\
\hline & Kulturní dějiny (Mg) & Muzeum umění & $2+0$ & A & $\mathrm{Zp}$ & Zatloukal \\
\hline
\end{tabular}

Tab. 8: Ostravská univerzita

\begin{tabular}{|c|c|c|c|c|c|c|}
\hline Fak. & Studijní obor & Předmět & Rozsah & Stat & $\mathrm{Ex}$ & Vyučující \\
\hline \multirow{5}{*}{ Filozofická fakulta } & Archivnictví (Bc) & Muzejnictví & $1+1$ & $\mathrm{C}$ & Ko & Podolský \\
\hline & \multirow{2}{*}{ Dějiny umění (Mg) } & Teorie a systém muzeí a galerií 1 & $2+0$ & A & $\mathrm{ZK}$ & \multirow{2}{*}{ Šopák } \\
\hline & & Teorie a systém muzeí a galerií 2 & $2+0$ & B & $\mathrm{Zp}$ & \\
\hline & Historie (Mg) & $\begin{array}{l}\text { Odraz hmotné kultury v muzejních } \\
\text { sbírkách }\end{array}$ & $0+2$ & B & Ko & \\
\hline & $\begin{array}{l}\text { Historie (Bc), } \\
\text { Archivnictví (Bc) }\end{array}$ & Inventarizace muzejních exponátů & $1+1$ & $\begin{array}{l}\mathrm{B}, \\
\mathrm{C}\end{array}$ & Ko & Podolský \\
\hline \multirow{2}{*}{$\begin{array}{l}\text { Pedagogická } \\
\text { fakulta }\end{array}$} & $\begin{array}{l}\text { Muzejní a galerijní pedagogika } \\
\text { Mg dvouoborové studium }\end{array}$ & více předmětů & $\begin{array}{l}\text { dvouleté } \\
\text { studium }\end{array}$ & & & doc. Šobáňová \\
\hline & $\begin{array}{l}\text { Historie se zaměřením na } \\
\text { vzdělávání }(\mathrm{Bc})\end{array}$ & Muzejnictví & $1+1$ & $\mathrm{C}$ & Ko & Podolský \\
\hline
\end{tabular}

Tab. 9: Univerzita Palackého v Olomouci

\section{FRANTIŠEK ŠEBEK}

Ústav historických věd, Filozofická fakulta, Univerzita Pardubice;

Ústav archeologie a muzeologie, Filozofická fakulta, Masarykova univerzita, Brno;

Česká republika 